\title{
Mathematical Meditations Revisiting Moral Practice in the Sciences of the Classical Age
}

\author{
Stéphane Van Damme
}

To what extent did scientists use the sciences to pursue the good life in the seventeenth century? How were the scientific revolution and ethical questioning connected? These are the apparently modest issues raised by the historian of science Matthew Jones in his book The Good Life in the Scientific Revolution. ${ }^{1}$ The project is noteworthy for two reasons. First, it is part of ongoing research into the social history of truth, which has encouraged numerous historians over the past two decades to explore the moral standards behind the use and elaboration of scientific practices. ${ }^{2}$ Second, civility, politeness and honor have given rise to specific research focusing on the cultural and social context in which scientific innovation was conducted in the Classical Age. Lastly, it is noteworthy because Jones investigates these questions more deeply by looking into how mathematical practice was seen as a challenge to, rather than a reflection of, these moral standards.

While much of the latest research in the history of science has focused on the globalization of the sciences that began on the threshold of the modern age,

This article was translated from French by Melanie Moore, revised by Stéphane Van Damme and edited by Stephen Sawyer.

1. Matthew L. Jones, The Good Life in the Scientific Revolution: Descartes, Pascal, Leibniz, and the Cultivation of Virtue (Chicago: University of Chicago Press, 2006).

2. Steven Shapin, A Social History of Truth: Civility and Science in Seventeenth-Century England (Chicago: University of Chicago Press, 1994). Since this book, there have been other attempts which tend towards adopting a plural model. For an intellectual history of "dissonant truths" that predates the chronology of Matthew Jones' book, see for instance Luca Bianchi, Pour une histoire de la double vérité (Paris: J. Vrin, 2008). 
Jones to the contrary has chosen an inward journey. And yet, this detour through the inner self in order to understand scientific practice is far from anachronistic or out of step with current historiography. Rather, it seeks to recall that the scientific revolution was born out of two ostensibly opposing movements. On the one hand, there was an external dynamic concerned with basing the moral authority of modern science on a single, dispassionate discourse by introducing the conceptual tools of the law and the common, regulated practices that separated the sciences from morality and politics. ${ }^{3}$ This process was embodied in the institutionalization of modern sciences, particularly in academies. On the other hand, there was an inner movement that consisted of strengthening the logic of interiority, allowing the individual voice to be heard and encouraging another way of incorporating knowledge that coincided with the moral thinking that was so important in the middle of the seventeenth century. The "culture of fact," as Barbara Shapiro has so eloquently described it, sought the point of intersection between these two spheres. On the level of the individual, it thrived on curiosity and the passion for collecting experiments as if they were rare specimens. On the level of the collective, it submitted to the discipline of the theater of proof. ${ }^{4}$

As Jones notes in his introduction, the spiritual exercises of St. Ignatius of Loyola acted as mediator between ancient traditions and the modern era. And yet, to paraphrase Michel de Certeau, to whom we shall be referring throughout this review, on the Jesuits' approach, "a logic of interiority served to counterbalance a logic of dissemination." 5 The intellectual and spiritual apostolate was situated between the universe of the mission or the school and that of the spiritual retreat. Knowledge acquired near at hand, in Europe, was not opposed to knowledge acquired at a distance. Similarly, a regime of publicity associated with the new culture of experiments was accompanied by a regime of proximity and clandestinity as displayed, for example, in the dialogue between Secretary of the Royal Society Henry Oldenburg and Baruch Spinoza about the publication of the latter's philosophical writings:

I would by all means advise you not to begrudge the learned those works in philosophy and theology, which you have composed with the talent that distinguishes you. Publish them, I beg, whatever be the verdict of petty theologians. Your country is free; the course of philosophy should there be free also. Your own prudence will, doubtless, suggest to you, that your ideas and opinions should be put forth as quietly as possible. For the rest, commit the issue to fortune. Come, then, good sir, cast away all fear of exciting against you the pigmies of our time. Long enough have we sacrificed to ignorance and pedantry.

3. Barbara J. Shapiro, Probability and Certainty in Seventeenth-Century England: A Study of the Relationships between Natural Science, Religion, History, Law, and Literature (Princeton: Princeton University Press, 1983). Simon Schaffer, "Making Certain," Social Studies of Science 14, no. 1 (1984): 137-52.

4. Barbara J. Shapiro, A Culture of Fact: England 1550-1720 (Ithaca: Cornell University Press, 2000). 
Let us spread the sails of true knowledge, and explore the recesses of nature more thoroughly than heretofore. Your meditations can, I take it, be printed in your country with impunity; nor need any scandal among the learned be dreaded because of them. If these be your patrons and supporters (and I warrant me you will find them so), why should you dread the carpings of ignorance? I will not let you go, my honoured friend, till I have gained my request; nor will I ever, so far as in me lies, allow thoughts of such importance as yours to rest in eternal silence. ${ }^{6}$

If Oldenburg's intervention moved the stakes of the debate at a time when Europe's great academies were being established, it was in order better to defend the practices of circulation and public discussion from censorship. The discussion invites debate on what was a very moral stance in the intellectual circles of the seventeenth century, which linked the virtues of learning with those of silence and withdrawal. In order to discredit that stance, Oldenburg was careful to merge it with the practice of concealment. ${ }^{7}$ For in Spinoza's case, Oldenburg was not only fighting against an imposed but also a voluntary isolation. He thereby used the issue of censorship skillfully against it. This marginal anecdote demonstrates the complexity of the reasoning often employed to establish what is at stake in morality, an issue that is commonly set aside in binary interpretation of the sciences in public. From the point of view of social history, the incipient Scientific Revolution has long been depicted as the triumph of the heroic figure of the academician over the grave and solitary figure of the scientist in his study or laboratory, using sociological terms that have often been vague and all-encompassing, fluctuating between the world of military virtues (honor, virility ${ }^{8}$ ) and the clerical world

6. Baruch Spinoza, Euvres, IV, Traité politique, Lettres, translation and notes by C. Appuhn (Paris: GF-Flammarion, 1966), 145, letter VII. For Spinoza's correspondence, see Henri Laux, "La correspondance," in Lectures de Spinoza, eds. P.-F. Moreau and C. Ramond (Paris: Ellipses, 2006), 203-19. More generally, see Pierre-François Moreau, Spinoza et le spinozisme (Paris: PUF, 2003). For relations with Oldenburg, see Marie Boas Hall, Henry Oldenburg: Shaping the Royal Society (Oxford: Oxford University Press, 2002), 61-63. 7. In his celebrated article "Spinoza" in the Dictionnaire historique et critique, Pierre Bayle recalls: "When Spinoza betook himself to the study of philosophy, he quickly grew out of conceit with the common systems and was wonderfully pleased with that of Descartes. He felt so strong an inclination to inquire after truth that he renounced the world in a manner the better to succeed in that inquiry. Not contented to free himself from all manner of business, he also left Amsterdam, because the visits of his friends too much interrupted his speculations. He retired into the country, where he meditated without any hindrance and made microscopes and telescopes." (Pierre Bayle, Pour une histoire critique de la philosophie. Choix d'articles philosophiques du Dictionnaire historique et critique, general introduction and presentation by J.-M. Gros, with the collaboration of J. Chomarat (Paris: Honoré Champion, 2001), 526).

8. For honor, see Catherine Goldstein, "L'honneur de l'esprit : de la République des mathématiques," in Dire et viore l'ordre social en France sous l'Ancien Régime, ed. F. Cosandey (Paris: Éd. de l'EHESS, 2005), 191-230, and Mary Terrall, "Gendered Spaces, Gendered Audiences: Inside and Outside the Paris Academy of Sciences," Configurations 3, no. 2 (1995): 207-32, on virility. Please note that honor has become a central historiographical category in the social history of the English-speaking world. 
(retreat, renunciation, etc. ${ }^{9}$ ). To the contrary, the Age of Enlightenment celebrated the civic and social values of politeness in the Marquis de Condorcet and FranzAnton Mesmer. ${ }^{10}$ Scientists' eulogies often acted as sources to justify these representations. ${ }^{11}$

In its attempt to find a better location for the point of connection between moral resources and the universe of science, Jones' book asks historians by contrast to explore this logic of "strengthening the interiority" of scientific practices. Scientific activities are sustained by a set of standards that are not external, but rather actively put to the test in the course of intellectual work. If the repositioning of the moral issue for the seventeenth-century scientist was a way of keeping religious and metaphysical questions at bay when engaged in science, an ethical horizon still had to be maintained when investigating nature.

\section{The Practical Morality of Mathematics: Three Routes}

In his investigations into a social history of truth, Jones uncovers three itineraries. Immersing himself first in René Descartes' Géométrie, published in 1637, he sets out to describe an art of thinking that is too often seen as stemming purely from the history of logic. Jones shows that, at the level of practical mathematics and the distinct tasks of the mathematician, a more general method was established that sought to resolve philosophical problems entirely and in all their complexity. Geometrisation and mathematisation were not the result of chance or a solution by default. They offered a set of "clear and distinct" rules, procedures and operations that were to exert a real fascination for Descartes' contemporaries and then for readers, from those of Père Lamy to those of Jean-Jacques Rousseau. In Jones' words, it emerged in fact as a "mathematical pedagogy." This is why it appealed so much to the Jesuits. ${ }^{12}$ Over and above the method of scientific investigation, geometry enabled the cultivation of the mind, its exercise, training and putting to the test. Jones is careful to remind us of the vocabulary that explained Descartes' recourse to this method. The ideas of "perseverance" and "firm resolution" clearly show just how compatible the scientific lexicon was with the moral philosophy of his day. At a time when French translations and new editions of Aristotle's

9. Harold Fisch, "The Scientist as Priest: A Note on Robert Boyle's Natural Theology," Isis 44, no. 3, (1953): 252-65; Simon Schaffer, "Godly Men and Mechanical Philosophers: Souls and Spirits in Restoration Natural Philosophy," Science in Context 1, no. 1 (1987): $55-85$.

10. Steven Shapin, "The Mind Is Its Own Place: Science and Solitude in SeventeenthCentury England," Science in Context 4, no. 1 (1991): 191-218.

11. Charles B. Paul, Science and Immortality: The Eloges of the Paris Academy of Sciences (1699-1791) (Berkeley: University of California Press, 1980).

12. See the work by Antonella Romano, La contre-réforme mathématique. Constitution et diffusion d'une culture mathématique jésuite à la Renaissance, 1540-1640 (Rome: École française de Rome, 1999); Peter Dear, Discipline \& Experience: The Mathematical Way in the Scientific Revolution (Chicago: Chicago University Press, 1995). 
Nicomachean Ethics were appearing (p. 103), the scientific undertaking could edify princesses as much as gentlemen. The book's second chapter completes this perspective by re-opening the file on relations between science and rhetorical proof but shifts the focus away from civility and the theatricality of the experience, which makes it a social and public event, and onto an analysis of the rhetorical structures of scientific discourse. Here we encounter a notion dear to Fernand Hallyn (sadly forgotten in the book), namely that the use of rhetoric is not solely a question of communication (p. 57) but refers also to the classical concepts of invention. Rhetoric is not sophistry but a good illustration of the will to knowledge. ${ }^{13}$ Beauty of style is not then irrelevant to the knowledge project, something that brings Descartes closer to other kinds of "poetic knowledge" (p. 58) such as music or poetry. Here, one would like to have seen Jones discuss Pierre-Alain Cahné's analyses of Descartes' language ${ }^{14}$ or Jean-Pierre Cavaillé's fable of the world and the theater metaphor (even if it does not relate to Cartesian mathematics), ${ }^{15}$ which remains central to the sciences of the late Renaissance, as Ann Blair has shown in relation to Jean Bodin. ${ }^{16}$ Jones sees here a rapprochement between Cartesian practice and Jesuit rhetorical pedagogy, particularly that of Nicolas Caussin.

With Blaise Pascal, Jones takes these discussions into the field of honesty and conversation. He shows how mathematics helped to deliver sound judgments and end disputes. On the basis of controversies about the vacuum and the calculating machine, Jones shows how the practices of mathematics were rooted in forms of sociability from the 1640s. According to Pascal, mathematical disputation should be raised to the level of an art of conversation and persuasion. Analysis of the discussions of Jacques Le Pailleur's circle reveals that the art of conversation was a constituent part of the mathematical exercise. The lack of this social skill explains why mathematician Gilles Personne de Roberval was said to be "just a geometrician." These thoughts about conversation lead to a chapter, central to the argument, on "the anthropology of disproportion" which makes it possible to re-examine the link between Pascal's mathematical practice and his Augustinianism.

13. Fernand Hallyn, Les structures rhétoriques de la science. De Kepler à Maxwell (Paris: Le Seuil, 2004), 12, compares two rhetorical approaches: the rhetorical approach that "studies techniques of argument and persuasion," and amounts to "observing the way in which established science presents itself to its audience," and the poetic approach, which "may also be called a 'deep rhetoric,' and explores how representations are formed. Its subject is science coming into being. It seeks in particular to find in the processes of invention and discovery the traces of an activity in which imagination is at work that is both tropological (generating semantic operations such as metonymy and metaphor, leading to conceptual transformations) and narrative (generating narratives such as thought experiences, like exploration and argumentation). Poetics or deep rhetoric addresses the utterance as text. It regards it as a structure or as a more or less consistent, formal and thematic composition, which has similarities to and differences from other compositions and structures that do not necessarily belong to the same domain but are the signs of heuristic work, the output of which has been deposited in them."

14. Pierre-Alain Cahné, Un autre Descartes. Le philosophe et son langage (Paris: J. Vrin, 1980).

15. Jean-Pierre Cavaillé, Descartes, la fable du monde (Paris: J. Vrin, 1991).

16. Ann Blair, The Theater of Nature: Jean Bodin and Renaissance Science (Princeton: Princeton University Press, 1997). 
This reflection on practices continues when it comes to Gottfried Wilhelm Leibniz and specifically his attempts to answer metaphysical, scientific and ethical questions by proposing an entire set of perspectival techniques drawn from his demonstration of squaring the circle. During the 1670 s and 1680 s, Leibniz wanted to give the games of optical illusion that were part of a gentleman's scientific amusements a central role in seeking to understand the hidden laws of nature. Perspective became the paradigmatic element in constructing science in general (p. 189). He therefore set himself the task of developing optical techniques which could help "skilful people" to imagine an object it its entirety. It was a question of making things in nature more visible. This insistence on materiality prompted Jones to describe all the projects written by Leibniz during this period, which had to do with techniques of notation and reading, and which added to the range of exercises already produced by tradition.

\section{The Shadow Cast by Pierre Hadot: Scientific Virtues and Spiritual Exercises}

Jones' choice of mathematics aims to highlight a singular aspect of the sciences in the Classical Age. Following on from the social history studies of Catherine Goldstein, Giovanna Cifolleti and Antonella Romano, he shows that mathematical practice was a strong point of departure for thinking about the complexity of modern sciences. ${ }^{17}$ Influenced by science studies, Jones adds to their tool box by putting other borrowings to work. He invites us to take seriously the work of the historian of ancient philosophy Pierre Hadot whose output is still little used by historians of science of the modern age. Hadot's lesson on philosophical methodology reads as follows:

This theoretical activity must be situated within a perspective that is different from that which corresponds to the idea people usually have of philosophy. In the first place, at least since the time of Socrates, the choice of a way of life has not been situated at the end of the process of philosophical activity, like a kind of accessory or appendix. On the contrary, it stands at the beginning, in a complex interrelation with critical reaction to other existential attitudes, with a global vision of a certain way of living and of seeing the world, and with the voluntary decision itself. Thus, to some extent this option determines the specific doctrine and the way this doctrine is taught. Philosophical discourse, then, originates in a choice of life and an existential option-not vice versa. ${ }^{18}$

Hadot suggests that scientific work be read as a spiritual exercise rather than merely a "system building" as in the past, a "discourse about discourses" open only to 
experts and places of learning: ${ }^{19}$ "We believe that like many modern works, they are designed to communicate information about a given conceptual content and that we can also draw from them precise information about the thinking and psychology of their author. In actual fact, however, they are very often spiritual exercises which the author practices himself and has his reader practice." 20 Three shifts sustain this approach: a move away from studying discourse alone; a move away from the central role of the academic or scientific institution; a move away from fetishizing the author. In response, there was a new focus on practices, on "wisdom" (the state of complete emotional freedom) and on the readership. ${ }^{21}$ However, far from simply replacing one definition of philosophy with another, Hadot showed that they constituted two aspects of intellectual work, which had never been entirely accepted and had led to heated controversies from ancient times to the Renaissance because they challenged the very idea of the autonomy of philosophical knowledge. ${ }^{22}$ In taking scientific practice seriously as practice, Jones is aware of these methodological requirements and does not set out to reduce the works of mathematics to a pure exercise in thinking. He wants to demonstrate its ethical component and the role played by imagination and sensibility, which go beyond the simple framework of intellectual exercises and correspond to "a transformation of one's vision of the world and a metamorphosis of one's personality." 23 In this way, Jones reintroduces in the context of the history of science the analysis of "the creative arts" between 1630 and 1670, a time when they were becoming codified and disseminated in print. ${ }^{24}$ "Making science" and "doing science" were to become increasingly synonymous. ${ }^{25}$ The search for mathematical truth was similar to a moral quest, an apprenticeship, a putting into practice of the rules of thinking and living well, to self-realization. For all that, this proposition was also limited by the framework of what was possible for intellectual work in the middle of the seventeenth century. As a spiritual exercise mathematics kept away from public settings and distanced itself from other ways of life and intellectual

19. Pierre Hadot, Exercices spirituels et philosophie antique (Paris: Études augustiniennes, 1981), 9.

20. Ibid., 9. See also Pierre Hadot, La philosophie comme manière de viore. Entretiens avec Jeannie Carlier et Arnold I. Davidson (Paris: Albin Michel, 2001), particularly chapter 6. 21. In the chapter "Spiritual Exercises," which defines his research program, Hadot, Exercices spirituels, 59-70, devotes page four to learning to read as one of the essential loci of spiritual training.

22. Juliusz Domanski, La philosophie, théorie ou manière de vivre? Les controverses de l'Antiquité à la Renaissance (Fribourg/Paris: Éd. universitaires/Éd. du Cerf, 1996). Domanski demonstrates that Petrarch and later Erasmus rejected the idea of a purely theoretical and descriptive ethic and refused to reduce "philosophers" to those who held university chairs.

23. See the nuances Hadot brings to using the notion of spiritual exercise, Exercices spirituelles, 26.

24. Bérangère Parmentier, "Arts de parler, arts de faire, arts de plaire. La publication des normes éthiques au XVII siècle," Littératures Classiques 37 (1999): 141-54.

25. From this point of view, see Christian Jacob, ed., Lieux de savoir, vol. I, Espaces et communautés; vol. II, Les mains de l'intellect (Paris: Albin Michel, 2007-10). 
traditions, such as cynicism which linked knowledge and truth together to act as trial and scandal, ${ }^{26}$ a model that would, moreover, be challenged by erudite freethinkers and taken up at the end of the century by Pierre Bayle. ${ }^{27}$

For Jones, it is not a question of linking these scientific practices to a norm that lay outside social practices but rather of finding the pedagogical and moral horizon of the sciences in the Classical Age through a close reading of the texts. He is keen to show the points of tangency with the universe of mathematics. One of the successes of mathematics could then be found in the social-philosophical form of the exercise, understood simultaneously as game, method and discipline. Indeed, with Descartes, the mathematical exercise became the paradigm for independent philosophical activity. ${ }^{28}$ Inquiry then consists of internalizing the moral question, whereas Steven Shapin would have sought to externalize it by making it comparable to other social contexts by first analyzing the formalities of etiquette, codes and manners that surround the civility of proof for each experiment. The social history of science thereby invites us to see the emergence of modern science through a social and cultural contextualization of its practices, dominated by the issue of making scientific pronouncements public and discussing them collectively. ${ }^{29}$ In order to convince and be validated, a scientific statement needed to have a proper literary form and to respect the social and cultural norms of a given place and society. This culture of experiment connected the notion of intellectual credibility to that of social credit. Ethics had a particular place here. Scientific work in this theater of proof consented to be morally shaped and to respect codes that were outside it. And yet, for Jones, classical science was the heir to ancient traditions. It is fashioned from the inside by a moral imperative that gives it not only

26. As Michel Foucault puts it in Le courage de la vérité. Le gouvernement de soi et des autres II. Cours au Collège de France, 1983-1984, ed. F. Gros, gen. eds. F. Ewald and A. Fontana (Paris: Gallimard/Le Seuil, 2009), 159: "So Cynicism is not satisfied with coupling or establishing a correspondence, a harmony or homophony between a certain sort of discourse and a life conforming to the principles stated in that discourse. Cynicism links mode of life and truth in a much tighter, more precise way. It makes the form of existence an essential part of truth-telling. It makes the form of existence the reductive practice which will make space for truth-telling. Finally, it makes the form of existence a way of making truth itself visible in one's acts, one's body, the way one dresses, and the way one conducts oneself and lives. In short, Cynicism makes life, existence, bios, what could be called an alethurgy, a manifestation of truth."

27. Heinrich Niehues-Pröbsting, "The Modern Reception of Cynism: Diogenes in the Enlightenment," in The Cynics: The Cynic Movement in Antiquity and its Legacy, eds. R. Bracht Branham and M.-O. Goulet-Cazé (Berkeley: University of California Press, 1996), 329-65, especially 330.

28. Catherine Goldstein, Un théorème de Fermat et ses lecteurs (Paris: Presses universitaires de Vincennes, 1995).

29. There is a shift from the paradigm of ceremonies and knowledge described in Steven Shapin and Simon Schaffer, Leviathan and the Air-Pomp: Hobbes, Boyle, and the Experimental Life (Princeton: Princeton University Press, 1985) to the paradigm of dramatic performance: Simon Schaffer, "Natural Philosophy and Public Spectacle in the Eighteenth Century," History of Science 51 (1983): 1-43; Jan Golinski, Science as Public Culture: Chemistry and Enlightenment in Britain, 1760-1820 (Cambridge: Cambridge University Press, 1992). 
shape but content, if not a higher justification. Jones thereby turns the mathematical exercise into an ascetic exercise that is all the greater for being practiced by scientific amateurs from various professional backgrounds and with diverse motivation. He goes beyond the accusations of reductionism or sociologism often put forward by philosophers to stigmatize any social approach to the "scientific revolution." Rather, from these debates, Jones retains the need to go further in describing scientific practices. Morality not only governed the scientist in his outward practice, in publishing his work or having it presented and accepted; it resided at the very core of practice and innovation.

This moral questioning opens up the landscape of the history of science to a second perspective encouraged by Hadot: that of looking at the sciences outside the framework of their disciplines. Like Dinah Ribard's studies of philosophy, ${ }^{30}$ the book seeks to redesign the borders between natural philosophy and nonphilosophy in the Classical Age ${ }^{31}$ Here though, rather than depicting this tension by analyzing places of learning or the "intellectual professions" where the logic of institutional and corporate recognition played itself out, Jones suggests that we restore all its significance to the "passion" for science when there is no apparent gratification or posts on offer. In selecting Descartes, Pascal and Leibniz, Jones endorses an institutionalized view of the sciences. He opposes the history of scientific disciplines with close attention to the various processes "disciplinarizing" scientific practice. Discipline does not imply hierarchy or an ordering of knowledge. It is above all habituation, aptitude and perseverance in training. With these three authors, the work of scientific revival appears eminently individual and seeks to internalize ethical norms. The values of honesty in Pascal or of charity in Leibniz are played out in routine scientific practice. The existential option made possible by mathematical practice corresponds to "a total life change, a conversion of the whole being and finally to a certain desire to be and to live in a particular way." 32

\section{From Moral Philosophies to Mathematical Tests}

In taking the mathematicians' moral philosophy seriously, Jones not only introduces us to an analysis of the mathematical practices of each of the authors studied but is also careful to place the issues inside each of their moral philosophies. For, far from being reduced to a pillar of Aristotelianism or a solid Stoicism, the thinking of these natural philosophers not only revives, but in fact redefines morality on the basis of their own concepts of the art of reasoning. The call to an unbroken or rediscovered intellectual tradition does not act as an ahistorical explanatory key. ${ }^{33}$

30. Dinah Ribard, "Réflexions sur l'écriture comme lieu de savoir dans les livres de philosophie en France au XVII siècle," Reoue de Synthèse 3, no. 4 (2007): 395-417.

31. Dinah Ribard, "Philosophie et non-philosophie : Fontenelle et Descartes," Revue Fontenelle 2 (2004): 55-68.

32. Hadot, Qu'est-ce que la philosophie antique?, 17-18.

33. This is the current direction chosen by an English-language history of philosophy that ponders the ways of transmission and the impact of reinventing traditions of 
They do not hold to the intellectual virtues defined in the Nicomachean Ethics nor to an alignment with the moral rules of antiquity within seventeenth-century rules of thinking. ${ }^{34}$ To study these three writers is to follow three mathematicians as they each put a different moral philosophy to the test.

Descartes aimed to subvert scholastic philosophy by questioning "practice": "The philosophy I seek, like all those devoted to its study, is nothing other than the knowledge of those truths which can be discovered by the natural light and may be of use to the human race: there is then no study more honorable, more worthy of mankind or of more use in this life," he wrote in his Épitre à Voetius in 1643. ${ }^{35}$ Intellectual reform, as for Francis Bacon, was a way of exploring the "kingdom of man," a way of thinking that was both a discourse on method and a treatise on the passions. Precise knowledge of the passions alone provides access to "universal bliss" through the pathways of personal asceticism. To counter litigious scholastic philosophy, Descartes defended a principle of generosity, a "generous action" to paraphrase Aristotle. ${ }^{36}$ There are hints of Stoic morality here. On the other hand, as Jones subtly demonstrates, Pascal had quite a different moral horizon and the question of happiness was regarded as inaccessible and, above all, evidence of reason's moral failure. Pascal demonstrated the limits of mathematics as a tool and of scientific knowledge. He highlighted the difficulties of holding together intention and the will, as was the custom in the Classical Age. As Christian Lazzeri writes, "in the field of scientific knowledge, will and understanding can only converge. But what happens outside that field?" 37 The certainty of good and fairness was couched in the same terms as within scientific investigation. The basis of the anthropology championed by Pascal was not in "nature" but in theology and the dual nature of man marked by original $\sin .{ }^{38}$ Lastly, for Leibniz, the pivotal concept was not of generosity but of charity. This was another philosophical and moral universe, that of a Christian philosophy that gave new life to its metaphysical foundations by introducing a requirement for order and method. ${ }^{39}$

antiquity, see, for example, Sarah Hutton, "Introduction," in Platonism at the Origins of Modernity: Studies on Platonism and Early Modern Philosophy, eds. D. Hedley and S. Hutton (Dordrecht: Springer, 2008), 1.

34. Aristotle, Éthique à Nicomaque, trans. R. Bodéüs (Paris: Flammarion, 2004), part six, "The intellectual virtues," 289-344.

35. Charles Adam and Paul Tannery, eds., CEuvres de Descartes, vol. VIII-B, 26 (Paris: J. Vrin, 1996), 2-7.

36. On generosity, see Denis Kambouchner, Descartes et la philosophie morale (Paris: Hermann, 2008), chap. IV.

37. Christian Lazzeri, "Pascal et le bonheur inaccessible," in Histoire raisonnée de la philosophie morale et politique. Le bonheur et l'utile, eds. A. Caillé, M. Senellart and C. Lazzeri, vol. 1 (2001; Paris: Flammarion, 2007), 401-14; here 409.

38. Jones, The Good Life, chap. 4.

39. Ibid., 169. 


\section{A Return of Morality in the History of Science?}

To what extent does this book mark the return of morality within the history of science after a period of some twenty years? As we know, such an operation was ruled out by a traditional epistemology that set facts against value in studying the rationality of science. Jones' approach is evidence that studies of mathematics and the formal sciences have been revisited from a more social perspective. But, it is also part of a broader movement that takes the connection between moral issues and the formulation of scientific problems seriously.

Shapin's latest book reinforces this awareness through his analysis of contemporary techno-sciences. ${ }^{40}$ The work, written more from a Weberian-Mertonian perspective, explores the issue of vocation or the scientist's moral engagement. It effectively begins with a questionnaire from classical sociology on the question of interest and thus seeks to probe the motives and registers cited to justify scientific activity and to challenge the legitimacy and relevance of disinterest in the context of modern science's great political and economic dependence. ${ }^{41}$ Long dismissed by historians and sociologists of science in favor of a collective, universal morality, the ethical issue, according to Shapin, can provide a better understanding of the scientist's charismatic aspect. This interpretation, which is always made on behalf of a disinterested view of the sciences, is intent on revealing behind-the-scenes operations and interests and insists on championing a pure science detached from economic interests, just as it was from morality and religion a few centuries before.

Jones puts the moral issue on quite another methodological level. The choice of this intellectual configuration (Descartes, Pascal and Leibniz) reveals the complexity of this moral questioning at a moment of crisis and tension without, however, seeking to take morality out of scientific activity. Rather than relating moral engagement and terms of justification to external and fixed orders of magnitude, Jones prefers to understand the practical and individual morality that informs the production of facts by referring to moral concepts that were being reconsidered. He highlights a very specific historical context. Moral values are no more stable or pre-established than the mathematical sciences. Where the law had provided the frame of reference needed to restore the authority of scientific proof, morality opened up a field in which the rules of mathematical practices could be applied. They were mutually reinforcing between 1620 and 1670 at a time when royal institutions seeking more absolutist expressions of knowledge were relatively weak, before the great academies were established, within the context of the Galileo affair, the fight against educated freethinking and the Thirty Years War. ${ }^{42}$ The moral

40. Steven Shapin, The Scientific Life: A Moral History of a Late Modern Vocation (Chicago: University of Chicago Press, 2008).

41. See Dominique Pestre, Sciences, argent et politique : essai d'interprétation (Paris: INRA Éditions, 2003).

42. For the tension between this absolutism and curiosity, see Hans Blumenberg's interpretation, La légitimité des Temps modernes (1988; Paris: Gallimard, 1999). See Jean-Claude 
authority of natural philosophy was less shored up by the patronage of the Church or Europe's great courts. It resided in a withdrawal into the self, in an interiority that had to be legitimized. In doing so, Jones gives a better account of the reciprocal influences between moral philosophy and natural philosophy without providing a questionnaire that would retroactively reconstitute a genealogy of the scientific vocation and the discourse of disinterest (or interest). It is not that seventeenthcentury scientists kept themselves aloof from social codes and values as the social and cultural history of science has amply demonstrated, but that the moral economy in question was not that of industrial and post-industrial societies. By putting the principles of generosity, charity and happiness back in their proper place, Jones' gamble to understand the moral challenge of scientific practice accurately and from the inside pays off, just as Michel de Certeau's once did for the "supernatural philosophy" of Argenson's master of requests. ${ }^{43}$ He thus reveals the operations that translate not just the contents, but the forms of moral philosophy into natural philosophy and vice versa. Jones thereby combines analysis of mathematical exercises with analysis of social and pedagogical measures. The Scientific Revolution is considered capable of bringing together the work of philosophy and an existential mode, science and ethics, and thereby of acquiring the power to seduce the collegetrained elites of the Old Regime who wanted to pursue a course of intellectual enlightenment in the science of numbers or geometry. At this point, practicing science became a moral disposition. Like the Jesuits' spiritual exercises, mathematics for these amateurs of the sciences were at the same time, to paraphrase Michel de Certeau once again, "a way of proceeding," "a space for desire" and a "will." 44

Jones' project is no longer about comparing systems of thought or closed and established contents but has more to do with demonstrating the existence of crossover points of a more analogical or morphological character. His investigation therefore has something in common with studies by Lorraine Daston, based on the notion of a "moral economy of science" in the Classical Age, ${ }^{45}$ Theodore Porter on statistics and Simon Schaffer on astronomy. ${ }^{46}$ For Daston, moral economy means highlighting a system of rules for organizing scientific activities in which morality matters. ${ }^{47}$

Monod's illuminating commentary, La querelle de la sécularisation. Théologie politique et philosophies de l'histoire de Hegel à Blumenberg (Paris: J. Vrin, 2002).

43. Certeau, "Politique et mystique. René d'Argenson (1596-1651)," Le lieu de l'autre, 265-300, on the "magistrate's supernatural philosophy," 269-76.

44. Ibid., 239-48.

45. Lorraine Daston, "The Moral Economy of Science," Osiris 10 (1995): 2-24.

46. Theodore Porter, "Objectivity as Standardization: The Rhetoric of Impersonality in Measurement, Statistics, and Cost-Benefit Analysis," Annals of Scholarship 9 (1992): 1959; Simon Schaffer, "Astronomers Mark Time: Discipline and the Personal Equation," Science in Context 2, no. 1 (1988): 115-45.

47. Daston, "The Moral Economy of Science," 4: "Here the term economy also has an old-fashioned meaning: it refers not to money, markets, labour, production or the distribution of material resources but rather to an organized system with certain regular features that can be explained but are not always predictable in their details." 
She moved away from Edward P. Thompson's usage of the concept in historiography as well as individual psychology and the search for intentions and "motivations." In other terms: 48 "the moral economy of science is more about self-discipline than coercion." ${ }^{49}$ Lorraine Daston thus suggests a determined move away from the Mertonian model of an ethos of the sciences deduced from observing scientific institutions. By taking moral observation back to the level of the individual, Jones also alters the Mertonian perspective. He does not describe exactly the same social space as that described by Peter Dear regarding the Jesuit college or by Shapin and Schaffer regarding the Royal Society or Boyle's laboratory or, again, by Mario Biagioli regarding the Florentine court, to quote just the usual examples. The change in the scale of analysis from the academic institution to the individual is certainly a relocation (that would go from the assembly and the academy to the workshop) but can also be seen as a de-socialization. The collective effort at issue here does not necessarily take the form of public science even if Jones does note the circulation of mathematical knowledge within social meeting circles and examine in the cases of Pascal and Leibniz the possibility of the method spreading into high society practices. Yet for all that, he does not confine himself to uncover intentionality or the concealed interests of scientific work. The mathematicians of the middle of the seventeenth century were caught in the net of a restricted but homogenous social network, held together by shared practices and codes of civility. ${ }^{50}$ The scientific ethic is not the sum of individual interests. The criticism offered by Jones is similar to the position of Donald Mackenzie who modified and challenged Shapin's approach by comparing it to a history of mathematical truths. ${ }^{51}$ He suggests creating a historical sociology of mathematical proof and in doing so compares two models: the inductive model of experimentation, which requires selected sociability, and the deductive model of mathematical knowledge "in which the individual is selfsufficient." ${ }^{2}$ He thus seeks to trace the specific social processes used by mathematical communities and shifts attention to practices of verification rather than replication.

\section{An Ethics of Truth: Re-Assessing the Cognitive Aspect of Passions}

The background to his presentation on the ethics of mathematics is the ongoing work on historical epistemology, ${ }^{53}$ which aims to take seriously the conditions in

48. Ibid., 3: "We can state more strongly and more specifically that certain forms of empiricism, quantification and objectivity themselves are not simply compatible with a moral economy: they call for moral economies."

49. Ibid., 6.

50. See Goldstein, "L'honneur de l'esprit”.

51. Donald Mackenzie, Mechanizing Proof: Computing, Risk, and Trust (Cambridge: MIT Press, 2001), 10-11.

52. Ibid., 11.

53. Here we can refer to the definition put forward by Lorraine Daston, "Une histoire de l'objectivité scientifique," in L'histoire des sciences. Méthode, styles et controversies, ed. 
which a passion for science was played out in the seventeenth century. ${ }^{54} \mathrm{Re}$ reading Descartes' Traité des passions, one cannot help but be surprised that it consists of describing and detailing the heuristic virtues of this form of emotion: admiration, observation, attention, etc. Many developments in Descartes' work have to do with this relationship between moral values and intellectual work, whether in Part Three on the "specific passions," such as gratitude, glory, generosity, esteem or contempt, that sustain a grammar of intellectual recognition, or Part Two on the “primitive passions": wonder (art. 53, art. 70-72), attention, astonishment (art. 73). Wonder, for example, is particularly well-endowed with cognitive virtues: "When something that is new to us comes before our intellect or our senses, we will not retain it in our memory unless the idea of it in our brain is strengthened by some passion or perhaps by a special state of attention and reflection that we choose to adopt." 55 These passions for the sciences make it possible to place a value on amateurs' work. ${ }^{56}$ To wonder, to pay attention, to be astonished are states that to a certain extent (without excess) "dispose us to the acquisition of the sciences," Descartes writes. ${ }^{57}$ This brings us back to one of Hadot's remarks about the Stoics: "Attention (prosoche) is the fundamental Stoic spiritual attitude. It is a continual vigilance and presence of mind, self-consciousness which never sleeps and a constant tension of the spirit." 58 Lorraine Daston has thus been able to identify on the part of the seventeenth-century naturalist Charles Bonnet a veritable devotion to attention that is found in the prescriptions in and commentaries to his natural history treatises: "In the work of Enlightenment naturalists such as Charles Bonnet and Adam Schirarch, the normative aspects of nature melted together, the useful into the beautiful, the oral into the sublime, the sacred into the pleasing." 59 The scientific and aesthetic fields and social and moral norms come together to justify

J.-F. Braunstein (Paris, J. Vrin, 2008), 367: "What I understand by historical epistemology is the history of the categories that structure our thought, that pattern our arguments and proofs, and certify our standards of explanation and give each of these activities symbolic meaning and an emotional value. This historical epistemology can (and indeed should) refer to the history of ideas and practices, as much as to the history of meanings and values that constitute the moral economies of the sciences."

54. Susan James, Passion and Action: The Emotions in Seventeenth-Century Philosophy (Oxford: Clarendon Press, 1997); Jacques Roux, Florian Charvolin and Aurélie Dumain, "Les 'passions cognitives' ou la dimension rebelle du connaître en régime de passion. Premiers résultats d'un programme en cours," Revue d'anthropologie des connaissances 3, no. 3 (2009): 369-85.

55. René Descartes, "Les passions de l'âme," Euvres philosophiques, vol. III, 1643-1650 (Paris: Bordas, 1989), 1010 (art. 75). See Denis Kambouchner, L'homme des passions. Commentaires sur Descartes, vol. I (Paris: Albin Michel, 1995), 237-40.

56. For attention, see Lorraine Daston, "Attention and the Values of Nature in the Enlightenment," in The Moral Authority of Nature, eds. L. Daston and F. Vidal (Chicago: University of Chicago Press, 2004), 100-26. L. Daston writes: "I can say that the value placed on nature was built on highly developed modes of attention, observation and description, applied to natural objects" (101).

57. Descartes, "Les passions de l'âme," 1011 (art. 385). 
and to stimulate investigations into nature. Still more recently, Lorraine Daston and Peter Galison have explored the same route in their invigorating essay on the history of objectivity where they show that the idea of objectivity gradually becomes established as a view from nowhere, running counter to the partisan logic of local attachment and social credit that long ensured the credibility of the modern sciences. ${ }^{60}$ The perfect model for mathematics, as analyzed by Jones, thus provides a regional model that could take its place alongside other epistemological systems which continued to assert their effectiveness and reputation until the eighteenth century: the paradigm of private and amicable exchange; ${ }^{61}$ the paradigm of secrecy and concealment that devised clandestine circulation, etc. ${ }^{62}$ The history of the scientific revolution would then consist of deploying these different systems of practice and of localizing rather than "vectorizing" them or placing them on a continuum. Similarly at the level of the individual, the search for truth does not appear as a "complete act" but as an effort of incomplete and endless realization that is close to a spiritual quest. ${ }^{63}$

\section{Shifting the Boundary Between Science and Religion}

What did scientific and mathematical thinking in the seventeenth century retain of authentically religious or spiritual ways of questioning? Not much, no doubt, if the analysis is reduced to questions with a theological or doctrinal content. And yet, this dimension appears everywhere in disputes, in justifications and in forms of publication. The metaphysical dimension does not vanish from scientific investigation but becomes increasingly restricted. This involves what Michel de Certeau called the "formality of practices," designating the shift from the religious practices of the Counter-Reformation to the ethic of practices defined by the Enlightenment. ${ }^{64}$ This proposal has been little understood by historians of science. ${ }^{65}$ Admittedly, research into relationships between the sciences and religion began a long time ago and has been much revived in the past twenty years, but the shift in historiography has often contributed to bringing religion back into the field of scientific practices from a Mertonian point of view, while taking no interest in the actual reconfiguration of the religious domain around scientific practices. ${ }^{66} \mathrm{In}$

60. Lorraine Daston and Peter Galison, Objectivity (New York: Zone Books, 2007).

61. Jean-Charles Darmon and Françoise Waquet, eds., L'amitié et les sciences. De Descartes à Lévi-Strauss (Paris: Hermann, 2010).

62. On this point, Nicholas Dew's recent book, Orientalism in Louis XIV's France (Oxford: Oxford University Press, 2009), endeavors to place the role played by free-thinkers like François Bernier inside the networks of baroque Orientalism; see chapter III.

63. To revisit the terms used by Gaston Bachelard, Essai sur la connaissance approchée (1928; Paris: J. Vrin, 1987), 13.

64. Michel de Certeau, L'écriture de l'histoire (Paris: Gallimard, 1975).

65. With the exception of Catherine Brice and Antonella Romano, eds., Sciences et religions de Copernic à Galilée, 1540-1610 (Rome: École française de Rome, 1999).

66. For this tension between religion and faith, see Philippe Büttgen and Christophe Duhamelle, eds., Religion ou confession. Un bilan franco-allemand sur l'époque moderne, $X V I^{e}$-XVIII ${ }^{e}$ siècles (Paris: Éd. de la MSH, 2010). 
acknowledging a therapeutic advantage to emotions and shifting the focus to how life was lived, scientists and churchmen nevertheless pondered how to make "practice" a place in which individuals' ways of seeing and being were transformed. In secularizing ethics, in detaching it from religious practice, scientific practice was able to take advantage of the effects of faith appropriate to dogma-based learning (theology, law, medicine), while keeping the scientific discourse well away from religious commitments. By reversing the great narrative of the scientific revolution, which was structured by the processes of academic scientific practices, the localization of scientific activities, the public acknowledgment and challenging of scientific announcements, the accumulation of data and artifacts, Jones describes a different model of scientific practices. This "moral economy of the sciences" might well be that of a minority but it is closer to other realms of practice such as religious or artisanal practice or even the educational practices of the Old Regime. It makes sense of the social presence mathematics had in ancient societies beyond any process of professionalization. Jones' historiographical positioning also makes it legitimate to contemplate the development of mathematical knowledge from the point of view of the culture of the amateur.

This is then an ambitious work. By embarking on this reflection, as we have seen, Jones escapes a history of mathematics as a kind of discipline or education in order to contemplate the relative importance of this new social and cultural practice in the societies of the modern era. The current resurgence of reflection on the practice of philosophy invites us to see mathematics as an ordinary cultural activity. ${ }^{67}$ This sort of investigation makes it possible to restore the sciences to a familiar place in the life of society, as exercise or creative art, as a way of life (spiritual, skeptical, etc.) or even as a way of looking after the self. It does justice to the oft-noted proximity of philosophy and meditation, philosophy and lifestyle (with freethinking being a striking example of this confusion), ${ }^{68}$ but it also makes a "social presence" outside the educational setting visible and legitimate. ${ }^{69}$ This may be reminiscent for the French reader of the interpretative framework used by Jean-Claude Perrot to examine the emergence of political economy as a social science through its proximity to Jansenist culture. ${ }^{70}$ For the seventeenth-century context, Jones' book enables the reshaping of research into science and ethics, which is not so directly linked to analyzing practices of civility, honor or reputation or the history of religions, but takes into account how understanding was affected

67. This trend is particularly strong in Romano Madera and Luigi Vero Tarca, La filosofia come stile di vita. Introduzione alle pratiche filosofiche (Milan: Bruno Mondadori, 2003). 68. Sandro Mancini, "Montaigne e il mestiere di vivere," in Pratiche filosofiche e cura di sé, eds. G. Achenbach and C. Brentari (Milan: Bruno Mondadori, 2006), 61-66.

69. These studies into philosophy's move away from discipline in the Classical Age stumble on this issue of philosophy spreading through society, still understood as a "vulgarization," a "disclosure" of a corpus of academic philosophy that is not concerned with describing the many ways of being present.

70. Jean-Claude Perrot, Une histoire intellectuelle de l'économie politique, XVII ${ }^{e}$-XVIII ${ }^{e}$ siècle (Paris: Éd. de l'EHESS, 1992). 
by the sciences' becoming part of morality. It would suddenly be possible for scientific practices to become more autonomous by integrating and respecting moral and social norms while the "religious" became both the subject of study and more secular. ${ }^{71}$ As recent historiography has amply demonstrated, attitudes differred in the Catholic and Protestant worlds. There is a long physico-theological tradition that enables an alliance between religion and science. Working further in this physicotheological domain, several historians have revealed the routes of transfer and complex accommodations..$^{72}$ The rejection of the body and ecclesiastical language legitimized a new scientific practice, within England's Rational dissenters and sects, that was able to refer to a spiritual tradition, as did John Wesley and Joseph Priestley. ${ }^{73}$ Similarly, in the second half of the eighteenth century, the exacerbation of sensibility and emergence of sentimentalism were to offer other ethical models to scientific practice. ${ }^{74}$ By taking the moral dimension of manufacturing the "modern" sciences seriously, Jones' analysis blurs an all too global division between sciences and religion, even as it takes seriously the forces behind a new scientific "belief." It shows the extent to which, when it came to efficacy, procedures and practices, the "modern" sciences drew on the spirituality and philosophies of the Classical Age. Within the social analysis of the sciences, it gives greater backing to the "formality of practices" rather than the study of content alone. Lastly, it recalls the importance on the threshold of the Enlightenment of a general practice of translating knowledge made possible through the support of a common architecture.

Stéphane Van Damme SciencesPo, Paris, Centre d'histoire

71. On the one hand, according to Certeau, in L'écriture de l'histoire, 156, "an autonomous ethic develops which takes either the social order or conscience as its frame of reference," on the other there is the development of a positive theology and a "clerical hermeneutic" that goes back to the origins of Christianity. "A science of morals now judges religious ideology and its impact where a 'science of faith' used to classify conduct in a sub-section that was entitled 'moral theology' and established a hierarchy of conduct according to the codes of the doctrine."

72. Jean-Robert Armogathe, La nature du monde. Science et exégèse au XVII siècle (Paris: PUF, 2007).

73. Numerous studies, such as those by John Christie for example, have referred to a reassessment of the relations between mysticism and science in the case of Joseph Priestley. See the classic articles by Simon Schaffer, "Priestley and the Politics of Spirit," in Science, Medicine and Dissent: Joseph Priestley, eds. R. G. W. Anderson and G. J. Lawrence (London: Wellcome Institute/Science Museum, 1987), 39-53; Id., "Measuring Virtue: Eudiometry, Enlightenment and Pneumatic Medicine," in The Medical Enlightenment of the Eighteenth Century, eds. R. K. French and A. R. Cunningham (Cambridge: Cambridge University Press, 1990), 281-318.

74. Jessica Riskin, Science in the Age of Sensibility: The Sentimental Empiricists of the French Enlightenment (Chicago: University of Chicago Press, 2002). 